\title{
Air Cucian Beras Sebagai Suplemen Bagi Pertumbuhan Bibit Kelapa Sawit
}

\author{
Rice Water As A Supplement For Growth Of Oil Palm Seeds
}

Rosafira Putri Zistalia, Mira Ariyanti, Mochamad Arief Soleh

Jln. Raya Bandung-Sumedang Km. 21 Jatinangor, Kab. Sumedang 45363 Jawa Barat

e-mail : rosafirap@gmail.com

\begin{tabular}{|l|l|}
\hline Diterima: 2 Juni $2018 \quad$ Disetujui: 25 Juni 2018 \\
\hline
\end{tabular}

Faktor yang mempengaruhi pertumbuhan tanaman kelapa sawit adalah pemberian unsur hara. Unsur hara yang biasa diberikan pada bibit kelapa sawit yaitu unsur N, P, K. Unsur hara tersebut dapat diperoleh dari pemberian pupuk organik, salah satunya yaitu yang berasal dari limbah air cucian beras. Air cucian beras banyak mengandung unsur yang bermanfaat bagi pertumbuhan bibit kelapa sawit diantaranya unsur $\mathrm{N}, \mathrm{P}, \mathrm{K} \mathrm{Mg}$, dan karbohidrat. Percobaan ini bertujuan untuk melihat pengaruh pemberian air cucian beras dengan konsentrasi dan interval waktu berbeda terhadap pertumbuhan bibit kelapa sawit. Percobaan ini dilaksanakan di Kebun Percobaan Ciparanje, Universitas Padjadjaran, Kabupaten Sumedang pada bulan Januari 2018 sampai dengan bulan April 2018. Jenis tanah yang digunakan adalah Inseptisol dengan tipe curah hujan bertipe $\mathrm{C}$ menurut klasifikasi Schmidt dan Ferguson. Penelitian ini menggunakan rancangan acak kelompok (RAK) dengan 13 perlakuan yang diulang sebanyak 3 kali dan tiap ulangan berjumlah 2 tanaman. Perlakuan meliputi pemberian pupuk anorganik dan pemberian air cucian beras dengan konsentrasi $25 \%, 50 \%, 75 \%$, dan $100 \%$. Interval waktu pemberian air cucian beras setiap hari, 3 hari sekali, 6 hari sekali. Hasil penelitian menunjukkan bahwa pemberian air cucian beras dengan konsentrasi $100 \%$ dan interval penyiraman 3 hari sekali pada bibit kelapa sawit berpengaruh baik terhadap pertumbuhan lilit batang dan jumlah daun.

Kata Kunci : Kelapa sawit, air cucian beras, limbah, konsentrasi.

\begin{abstract}
Factor affecting the growth of oil palm is nutrients supply. N, P, K are macro nutrients given to oil palm seedlings. Nutrition could be obtained from provision of organic fertilizer such as from rice water waste. It contains a lot of beneficial elements for the growth of oil palm seedlings such as $\mathrm{N}$, $\mathrm{P}, \mathrm{K}, \mathrm{Mg}$, and Carbohydrates. This study aimed to examine the effect of rice water waste with different concentrations and time intervals on the growth of oil palm seedlings. The experiments were conducted in Experiment Station of Ciparanje, Faculty of Agriculture, Universitas Padjadjaran, Sumedang,from January 2018 to April 2018. Ordo of the soil used was Inceptisol with precipitation type according to Schmidt and Ferguson's. A randomized block design used on the experiments with 3 times repetition of 13 treatments and 2 plants on each repetition. Inorganic fertilizer and rice water waste with different concentrations $(25 \%, 50 \%, 75 \%$, and $100 \%)$ were given to the oil palm seedlings. Rice water waste were given daily, once in 3 days, once in 6 days. The results showed that provision of $100 \%$ concentrated rice water waste given once in 3 days on oil palm seedlings had a significant effect on the growth of girth and leaves.
\end{abstract}

Keywords : Oil palm, rice water waste, waste, concentration. 


\section{PENDAHULUAN}

Tanaman kelapa sawit (Elaeis guineensis Jacq.) merupakan salah satu tanaman perkebunan dengan jumlah produksi yang tinggi di Indonesia (Pakpahan dkk, 2015). Perkebunan kelapa sawit tersebar luas di seluruh Indonesia, salah satunya di Provinsi Riau merupakan perkebunan kelapa sawit terluas di Indonesia (Direktorat Jenderal Perkebunan, 2015). Perkebunan kelapa sawit yang sangat luas di Indonesia menghasilkan jumlah produksi yang tinggi. Produksi kelapa sawit di Indonesia pada tahun 2014 yaitu mencapai 29.278.189 ton (FAO, 2016).

Proses peningkatan produksi bibit kelapa sawit salah satunya dapat dilakukan dengan cara penggunaan bibit yang berkualitas dan daya tumbuh tinggi (Sudarso dkk, 2015). Pertumbuhan bibit kelapa sawit yang baik dapat dihasilkan dari tercukupinya unsur hara untuk pertumbuhan dan perkembangannya. Hal ini perlu diperhatikan karena pembibitan kelapa sawit merupakan titik awal yang sangat menentukan bagi pertumbuhan kelapa sawit selanjutnya (Purniawati dkk, 2015).

Pemberian unsur hara $\mathrm{N}, \mathrm{P}$, dan $\mathrm{K}$ dapat meningkatkan pertumbuhan bibit kelapa sawit (Mukhtaruddin dkk, 2015). Unsur nitrogen merupakan salah satu unsur yang sangat dibutuhkan bagi pembibitan kelapa sawit, hal ini dikarenakan unsur tersebut berperan dalam pembentukan dan pertumbuhan vegetatif tanaman seperti daun dan akar (Sitio dkk, 2015). Salah satu cara untuk memenuhi kebutuhan unsur hara pada bibit kelapa sawit adalah dengan memberikan pupuk organik.

Pupuk organik yang biasa digunakan dalam pembibitan kelapa sawit adalah pupuk kompos dan pupuk kandang, namun pupuk organik juga dapat berasal dari limbah rumah tangga yaitu air cucian beras. Air cucian beras mengandung unsur hara yang cukup untuk pertumbuhan tanaman, sehingga dapat menjadi salah satu pupuk organik alternatif atau suplemen tambahan bagi pertumbuhan bibit kelapa sawit. Hal ini dikarenakan air cucian beras lebih mudah didapatkan dan bernilai lebih ekonomis. Air cucian beras mengandung vitamin $B_{1}$ yang berperan dalam proses metabolism tanaman untuk mengkonversi karbohidrat menjadi energi aktivitas pertumbuhan di dalam tanaman (Samahah, 2015). Kandungan vitamin $B_{1}$ pada air cucian beras dapat merangsang pertumbuhan akar pada masa pembibitan menjadi lebih cepat (Wulandari dkk, 2011). 
Pertumbuhan bibit kelapa sawit juga dapat dipicu dari penyediaan media tumbuh dengan memperhatikan aerasi dan ketersediaan air. Kelapa sawit memiliki perakaran serabut, sehingga mudah mengalami cekaman kekeringan (Dwiyana dkk, 2015). Tanaman kekeringan juga dapat disebabkan dari transpirasi yang tinggi dan ketersediaan air tanah yang terbatas saat musim kemarau (Dwiyana dkk, 2015). Salisbury dan Ross (1997) dalam Dwiyana dkk (2015) menyatakan bahwa air berperan sebagai pelarut unsur hara dari dalam tanah masuk ke dalam tanaman, sebagai penyusun utama dari protoplasma serta mengatur suhu bagi tanaman. penggunaan air yang berlebihan juga dapat menurunkan pertumbuhan tanaman karena unsur hara mengalami pencucian, sehingga penyiraman dengan interval waktu yang panjang dapat menghindari pemadatan tanah dan unsur hara dapat terserap dengan cukup oleh tanaman (Haryati, 2003).

Pada penelitian ini dilakukan pengamatan terhadap pertumbuhan bibit kelapa sawit yang diberi air cucian beras sebagai suplemen atau pupuk organik alternatif dengan konsentrasi dan interval waktu pemberian air cucian beras yang berbeda.

\section{METODE PENELITIAN}

Penelitian telah dilaksanakan di Kebun Percobaan Ciparanje Fakultas Pertanian, Universitas Padjadjaran, Kecamatan Jatinangor, Kabupaten Sumedang, Jawa Barat. Penelitian ini dilaksanakan dari bulan Januari 2018 sampai April 2018.

Bahan yang digunakan diantaranya adalah bibit kelapa sawit varietas Simalungun berumur 6 bulan. Media tanam yang digunakan adalah campuran tanah dan pupuk kompos dengan perbandingan 2:1. Penggunaan air cucian beras bilasan pertama sebagai suplemen tambahan. Pupuk anorganik NPK majemuk (15:15:6,5) pada bulan pertama dan pupuk NPK majemuk (12:12:17) pada bulan kedua sampai keempat. Penggunaan polybag berukuran 40 $\mathrm{cm} \times 40 \mathrm{~cm}$.

Alat yang digunakan diantaranya adalah meteran, gelas ukur, thermometer, timbangan analitik, klorofil meter SPAD, dan scanner.

Penelitian ini menggunakan Rancangan Acak Kelompok (RAK) yang terdiri dari 13 perlakuan. Masing-masing perlakuan diulang sebanyak 3 kali dan tiap ulangan terdiri dari 2 tanaman, sehingga jumlah bibit kelapa sawit yang digunakan 
sebanyak 78 bibit. Konsentrasi dan interval waktu air cucian beras yang digunakan sebagai berikut:

$\mathrm{A}=$ Pupuk anorganik NPK majemuk total 94 gram

$\mathrm{B}=25 \%$ air cucian beras disiram setiap hari $\mathrm{C}=25 \%$ air cucian beras disiram 3 hari sekali

$\mathrm{D}=25 \%$ air cucian beras disiram 6 hari sekali

$\mathrm{E}=50 \%$ air cucian beras disiram setiap hari

$\mathrm{F}=50 \%$ air cucian beras disiram 3 hari sekali

$\mathrm{G}=50 \%$ air cucian beras disiram 6 hari sekali

$\mathrm{H}=75 \%$ air cucian beras disiram setiap hari $\mathrm{I}=75 \%$ air cucian beras disiram 3 hari sekali $\mathrm{J}=75 \%$ air cucian beras disiram 6 hari sekali

$\mathrm{K}=100 \%$ air cucian beras disiram setiap hari

$\mathrm{L}=100 \%$ air cucian beras disiram 3 hari sekali

$M=100 \%$ air cucian beras disiram 6 hari sekali

Penelitian ini dilaksanakan dengan melakukan persipan bahan tanam dan penanaman terlebih dahulu. Media tanam campuran tanah dan pupuk kompos (2:1) dimasukkan ke dalam polybag, kemudian dibuat lubang tanam untuk memasukkan bibit kelapa sawit. Bibit kelapa sawit yang telah ditanam dalam polybag tersebut disiram menggunakan air cucian beras dengan konsentrasi dan interval waktu yang telah ditentukan sesuai perlakuan. air cucian beras yang digunakan adalah air cucian bilasan pertama. Jumlah total air cucian beras dan air yang digunakan sebanyak satu liter sesuai dengan kapasitas lapang polybag yang digunakan. Pembuatan larutan air cucian beras dilakukan dengan cara sebagai berikut:

1. Air cucian beras $25 \%=250$ $\mathrm{ml}$ air cucian beras $+750 \mathrm{ml}$ air.

2. Air cucian beras $50 \%=500$ $\mathrm{ml}$ air cucian beras $+500 \mathrm{ml}$ air.

3. Air cucian beras $75 \%=750$ $\mathrm{ml}$ air cucian beras $+250 \mathrm{ml}$ air.

4. Air cucian beras $100 \%=1000$ $\mathrm{ml}$ air cucian beras. 
Pemeliharaan bibit kelapa sawit dilakukan dengan cara penyiangan pada gulma dan menggunakan pestisida decis jika terdapat bibit yang terserang hama. Parameter pengamatan yang dilakukan diantaranya adalah bobot basah akar, bobot basah tajuk, bobot kering akar, bobot kering tajuk, dan indeks klorofil daun.

\section{HASIL DAN PEMBAHASAN}

\section{Bobot Basah Akar dan Tajuk}

Pada Gambar 1 menunjukkan bahwa pemberian air cucian beras tidak berbeda nyata dengan pemberian pupuk anorganik pada bibit kelapa sawit terhadap bobot basah akar dan bobot basah tajuk. Perlakuan C $(25 \%$ air cucian beras disiram 3 hari sekali) cenderung memberikan hasil yang baik terhadap bobot basah akar bibit kelapa sawit, sedangkan perlakuan K (100\% air cucian beras disiram setiap hari) cenderung memberikan hasil yang baik terhadap bobot

basah tajuk bibit kelapa sawit. Hal ini diduga interval pemberian air cucian beras pada perlakuan $\mathrm{C}$ dan perlakuan $\mathrm{K}$ mencukupi kebutuhan unsur hara bobot basah akar dan tajuk bibit kelapa sawit.
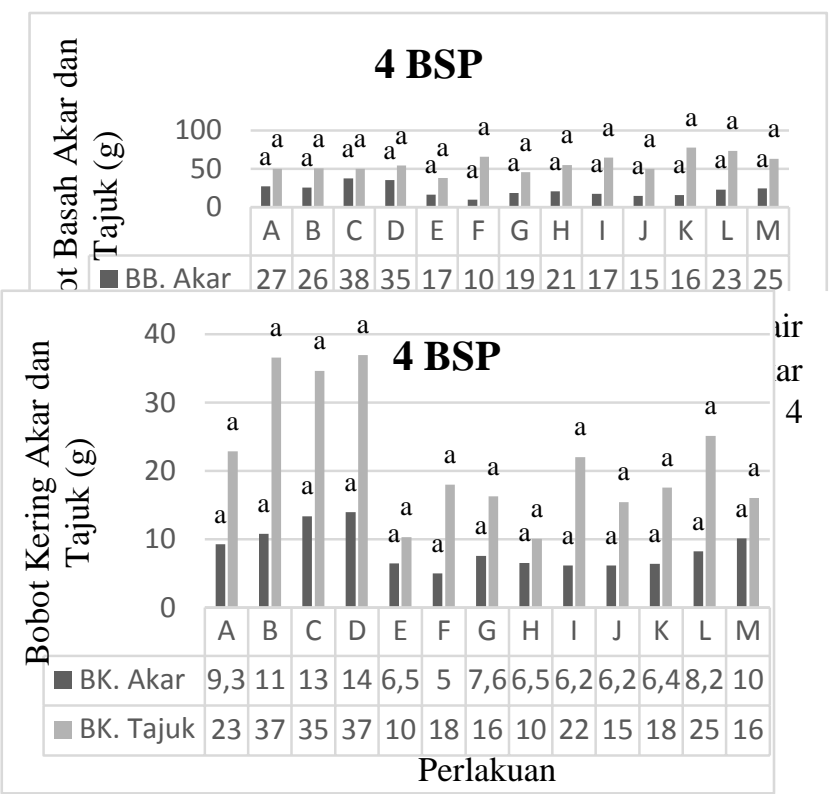

Penyerapan air di dalam tanah dapat mempengaruhi perkembangan bobot basah tanaman. Aerasi tanah yang baik akan membuat respirasi akar tanaman lebih baik dan juga dapat menaikkan tingkat pertumbuhan tanaman. Hakim dkk (1986) dalam Afrillah dkk (2015) menjelaskan bahwa tekstur tanah sangat mempengaruhi kemampuan daya serap air, ketersediaan air di dalam tanah, besarnya aerasi, infiltrasi dan laju pergerakan air.

Tekstur tanah yang digunakan sebagai media tanam pertumbuhan tanaman sangat mempengaruhi pertumbuhan baik untuk perakaran maupun bagian tanaman yang lainnya (Afrillah dkk, 2015). Kandungan unsur hara yang ada dalam air cucian beras mampu memacu pertumbuhan bibit kelapa

Gambar 2. Diagram pengaruh pemberian air cucian beras terhadap bobot kering akar dan tajuk bibit kelapa sawit pada 4 BSP 
sawit, namun belum mampu terserap dengan baik karena hasil menunjukkan tidak ada pengaruh yang nyata pada setiap perlakuan.

\section{Bobot Kering Akar dan Tajuk}

Pada Gambar 2 dapat dilihat bahwa pemberian air cucian beras pada bibit kelapa sawit tidak berbeda nyata dengan pemberian

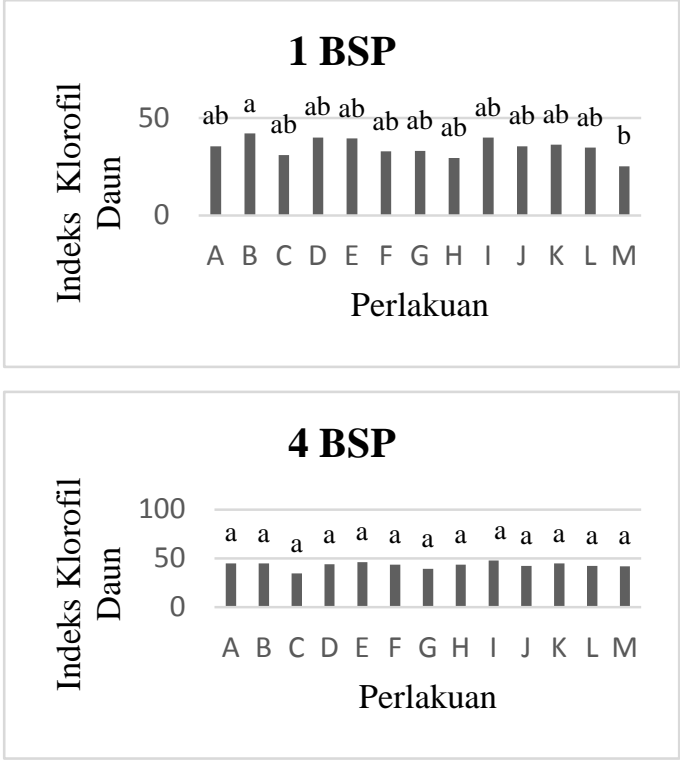

pupuk anorganik, namun perlakuan D (25\% air cucian beras disiram 6 hari sekali) cenderung memberikan hasil yang baik terhadap bobot kering akar dan tajuk bibit kelapa sawit. Hal ini diduga interval penyiraman 6 hari sekali mampu mencukupi kebutuhan unsur hara untuk bobot kering tanaman. Bobot kering akar dan tajuk menunjukkan tingkat efisiensi metabolisme tanaman. Bahan kering diakumulasi sebagai indikator ukur untuk pertumbuhan tanaman. Akumulasi bahan kering memperlihatkan kemampuan tanaman dalam mengikat energi dari cahaya matahari melalui adanya proses fotosintesis serta karena adanya suatu interaksi antara tanaman dengan faktor lingkungan (Afrillah dkk., 2015). Bobot kering tanaman merupakan hasil penimbunan bersih fotosintesis selama periode pertumbuhan, sehingga berat kering tanaman menjadi meningkat dan dijadikan sebagai indikator pertumbuhan. Hal ini dikarenakan bobot kering tanaman menunjukkan hasil tanaman yang diperoleh dari total pertumbuhan dan perkembangan dari awal pertumbuhannya (Sukarno, 2001).

Gambar 3. Diagram pengaruh pemberian air cucian beras terhadap indeks klorofil daun bibit kelapa sawit pada 4 BSP

\section{Indeks Klorofil Daun}

Gambar 3 menunjukkan bahwa pada 4 BSP pemberian air cucian beras menunjukkan pengaruh yang tidak berbeda nyata dengan pemberian pupuk anorganik, namun perlakuan I (75\% air cucian beras disiram 3 hari sekali) cenderung 
memberikan hasil yang baik terhadap kandungan klorofil daun bibit kelapa sawit. Hal ini diduga adanya faktor lingkungan yang mempengaruhi kandungan klorofil pada bibit kelapa sawit, namun unsur hara yang terkandung pada perlakuan I mencukupi untuk kandungan klorofil daun bibit kelapa sawit.

Kandungan klorofil daun diduga dipengaruhi oleh interval penyiraman. Interval penyiraman berperan penting dalam menentukan kandungan klorofil daun, karena kekurangan air dapat mempengaruhi kandungan dan struktur klorofil di dalam kloroplas (Syafi, 2008). Kandungan klorofil pada daun berguna pada tanaman untuk melakukan fotosintesis. Klorofil daun terbentuk dari pemanfaatan unsur hara nitrogen oleh tanaman. Unsur hara nitrogen yang cukup dapat menghasilkan klorofil yang baik bagi tanaman dalam melakukan fotosintesis (Wardiana dan Zainal, 2003). Kandungan hara nitrogen pada air cucian beras diduga mampu memberikan pengaruh yang baik untuk pembentukan zat hijau daun bagi pertumbuhan bibit kelapa sawit.

\section{KESIMPULAN DAN SARAN}

Pemberian air cucian beras pada bibit kelapa sawit tidak memberikan pengaruh nyata terhadap parameter bobot basah akar, bobot basah tajuk, bobot kering akar, bobot kering tajuk, dan indeks klorofil daun.

Perlu adanya penambahan konsentrasi dan penyiraman dengan interval waktu yang tepat agar pemberian air cucian beras dapat berpengaruh dengan baik sebagai suplemen tambahan, sehingga dapat dihasilkan pertumbuhan yang tinggi pada bibit kelapa sawit.

\section{DAFTAR PUSTAKA}

Afrillah, M., F. E. Sitepu, dan C. Hanum. 2015. Respons pertumbuhan vegetatif tiga varietas kelapa sawit di pre nursery pada beberapa media tanam limbah. Jurnal Online Agroteknologi, 3(4), 1289-1295.

Direktorat Jenderal Perkebunan. 2015. Statistik Perkebunan Indonesia 2014 - 2016Kelapa Sawit. Jakarta: Kementerian Pertanian.

Dwiyana, S. R., Sampoerno, dan Ardian. 2015. Waktu dan volume pemberian air pada bibit kelapa sawit (Elaeis guineensis Jacq.) di main nursery. JOM Faperta 2(1).

FAO. 2016. FAOSTAT data 6-1-2017. Terdapat di http://www.fao.org/faostat/en/\#data/ QC. Diakses pada tanggal 24 November 2018.

Haryati. 2003. Pengaruh cekaman air terhadap pertumbuhan dan hasil 
tanaman. Fakultas Pertanian Universitas Sumatera Utara. Medan. Mukhtaruddin, Sufardi, dan A. Anhar. 2015. Penggunaan guano dan pupuk NPK mutiara untuk memperbaiki kualitas media subsoil dan pertumbuhan bibit kelapa sawit (Elaeis guineensis Jacq.). Jurnal Floratek, 10(2), 19-30.

Pakpahan, S., Sampoerno, dan S. Yoseva. 2015. Pemanfaatan kompos solid dan mikroorganisme selulolitik dalam media tanam pmk pada bibit kelapa sawit (Elaeis guineensis Jacq.) di pembibitan utama. JOM Faperta, 26(4), 2-7.

Purniawati, D. I., Sampurno, dan Armaini. 2015. Pemberian air kelapa muda dan air cucian beras pada bibit karet (Hevea brasiliensis) stum mata tidur. JOM Faperta, 7(2), 493-510.

Samahah, N. 2015. Pengolahan air leri menjadi sabun pembersih wajah yang alami dan ekonomis. Prosiding Seminar Nasional Kimia, ISBN: 978-602-0951-05-8, 26-27.

Sitio, Y., G. Wijana, dan I. G. N. Raka. 2015. Pemanfaatan tandan kosong kelapa sawit dan pupuk nitrogen sebagai subsitusi topsoil terhadap pertumbuhan bibit kelapa sawit (Elaeis guineensis Jacq.) periode pre nursery. E-Jurnal Agroekoteknologi Tropika, 4(4) ISSN: 2301-6515, 264266.

Sudarso, Nelvia, dan K. Amrul. 2015. Pemberian zat pengatur tumbuh (zpt) alami pada bibit kelapa sawit (Elaeis guineensis Jacq.) di main nursery. JOM Faperta, 2(2), 1-3.

Sukarno, A. 2001. Pengaruh ukuran polybag dan jenis media tanam terhadap pertumbuhan semai sengon laut (Paraserianthes falcataria). Jurnal Agritek. 9(4):34-38.

Syafi, S. 2008. Respons morfologis dan fisiologis bibit berbagai genotipe jarak pagar (Jatropha curcas L.) terhadap cekaman kekeringan. Thesis Institut Pertanian Bogor.

Wardiana, E. dan M. Zainal. 2003. Tanaman sela diantara pertanaman kelapa sawit. Jurnal Lokakarya Sistem Integrasi Kelapa Sawit. Loka Penelitian Tanaman Sela Perkebunan, Parung Kuda. Parung Kuda, Jawa Barat.

Wulandari, C., S. Muhartini, dan S. Trisnowati. 2011. Pengaruh air cucian beras merah dan beras putih terhadap pertumbuhan dan hasil selada (Lactuca sativa L.). Jurnal Fakultas Pertanian Universitas Gadjah Mada, Yogyakarta. 